\title{
Scleroderma Polymyositis Overlap Syndrome
}

National Cancer Institute

\section{Source}

National Cancer Institute. Scleroderma Polymyositis Overlap Syndrome. NCI Thesaurus.

Code C113723.

A rare autoimmune disorder in which patients present with overlapping symptoms of systemic scleroderma and polymyositis or dermatomyositis. 